\title{
Bretton Woods 2.0? Rebuilding Global Governance for the Post-pandemic Era
}

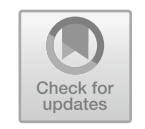

\author{
Huiyao Wang
}

\begin{abstract}
In the first half of the twentieth century, in the absence of effective global governance mechanisms, unchecked forces of fragmentation, economic hardship, and polarization led to two devastating world wars. To prevent this from happening again, after the Second World War, countries from around the world came together at Bretton Woods and other landmark conferences to build a new system of global governance that would promote international cooperation, stability, and peace and prosperity. Today, like after the Second World War, the world faces major challenges, not only in the short term to recover from the pandemic but also in the long term to overcome global threats like climate change, which no country can solve alone. As we emerge from COVID-19, there is a unique opportunity for a long-overdue “Bretton Woods 2.0" moment to rethink global governance and forge multilateral institutions that better reflect the realities of the post-pandemic world. China can, and should, help lead by supporting the update and strengthening of existing institutions. For example, the Asia Infrastructure Investment Bank should be transformed into the Global Infrastructure Investment Bank. Overall, China should be drawing on its knowledge as the longest continuous civilization in the world and using these strengths to propose its own solutions to pressing global issues.
\end{abstract}

Keywords The absence of effective global governance mechanisms • The world came together at Bretton Woods - To build a new system of global governance • Promote international cooperation, stability and peace and prosperity $\cdot$ Global threats like climate change, which no country can solve alone $\cdot$ A long-overdue "Bretton Woods 2.0" moment

Global governance can have a significant impact on how the world recovers from a major catastrophe. After the twin tragedies of the First World War and the Spanish Flu pandemic of 1918-19, the newly formed League of Nations was unable to prevent a vicious cycle of nationalism, protectionism, and economic hardship that would wipe out two-thirds of international trade, plunge the world into the Great Depression, and ultimately sow the seeds of the Second World War.

\footnotetext{
H. Wang (凶)

Center for China and Globalization (CCG), Beijing, China

(C) The Author(s) 2021

H. Wang and A. Michie (eds.), Consensus or Conflict?, China and Globalization, https://doi.org/10.1007/978-981-16-5391-9_11
} 
The contrast with the aftermath of the Second World War is striking. Even before the war ended, allied leaders were putting together pieces of a new system of global governance to support a more constructive economic and international order. In 1944, delegates from 45 nations descended on New Hampshire for the Bretton Woods conference to devise institutions that would govern the post-war international monetary system, including the International Monetary Fund (IMF) and the World Bank. Just under a year later, delegates from around the world met in San Francisco to create the United Nations Charter, which established the purposes, governing structure, and framework of the UN system. This was followed by the signing of the General Agreement on Tariffs and Trade (GATT), the forerunner of the World Trade Organization (WTO), in Geneva in October 1947.

Assembled in just a few short years, these institutions became the building blocks of "Global Governance 1.0"- the international system that remains to this day. While far from perfect, the system of global governance based on the UN and Bretton Woods institutions succeeded in preventing the world from sliding into another allout global conflict in the challenging conditions that followed two devastating wars. Economic arrangements that grew out of Bretton Woods helped feed a virtuous cycle of openness, trade, prosperity, and stability. Trade barriers fell and global foreign direct investment grew eight times from 1950 to 1970. At the same time, governments took a long-term perspective and made sustained investments in human and physical infrastructure, most famously the Marshall Plan, which helped to rebuild and modernize economies in Europe.

As the world struggles to get back on its feet after COVID-19, such divergent outcomes after the two world wars provide valuable lessons for our times. The first is that major external shocks like a war-or a pandemic_ — can be a catalyst for sweeping reforms of global governance. The second is that the ability of global governance to adapt to a new post-crisis environment and perform crucial functions can have a major long-term impact on geopolitics and the trajectory of the global economy.

Like a global conflict, the pandemic has claimed millions of lives and caused untold disruption to people's lives and economies around the world. Its effects will linger for many years and the UN is warning of a "lost decade" for development. But the pandemic has also triggered a serious discussion about globalization and global governance, and broadened the spectrum of possibilities for what comes next. Kristalina Georgieva, IMF Managing Director, has declared that we face a new "Bretton Woods moment" and may need to reorient global institutions to the demands of our times. UN Secretary-General António Guterres has called for a fundamental rethink and reform of global governance to bring about a stronger and more inclusive multilateralism.

The architects of the post-war world recognized that global problems need global attention. COVID-19 has led to a similar consensus that global governance must be reformed to meet the challenges of the post-pandemic era. But what should this new system of "Global Governance 2.0" look like? Building on an analysis of the key features and trends shaping the post-pandemic world and the challenges and the implications this has for global governance, this essay sketches some contours of 
what Bretton Woods 2.0, or better still Global Governance 2.0, might look like. Also proposed are the five steps China could take to contribute to its emergence.

\section{Key Trends Shaping the Post-pandemic Global Landscape}

COVID-19 should have been a chance for global governance to shine. Pandemics are a prime example of a transnational threat that no country can solve alone. Unfortunately, rather than show the enduring relevance of multilateralism, the pandemic and our failure to mount an effective international response did more to expose the fractures and fragilities in our current system of global governance.

Multilateralism had been under increasing strain long before the outbreak. In part, this is due to long-term structural shifts which the system has failed to adapt to. As we start to imagine a renewed system of global governance, it is important to understand five "megatrends" that have strained global governance 1.0 and that any new international system will have to accommodate and adapt to. As discussed below, this is particularly so as, in many ways, the pandemic will only serve to strengthen and accelerate these trends, creating a post-pandemic world that is more multipolar, interdependent, digital, and marked by rising regionalism and geoeconomics.

\subsection{A More Multipolar World}

The first reality that any new system of global governance must accommodate is that we live in an increasingly multipolar world. The existing US-led system was designed for a world where power was highly concentrated. However, long-term structural trends, in particular the rise of developing countries, mean that in the postpandemic era, no single power will be able to dictate global norms and rules by itself.

Nowhere is the shift to multipolarity more evident than in the rise of Asia. By many measures, Asia's economy is now bigger than the rest of the world combined, for the first time since the nineteenth century. Post-pandemic recovery trajectories will likely reinforce this shift. While there are significant differences between individual countries, overall, Asia suffered less and is coming out of the pandemic earlier compared to Europe and America, meaning economic recovery will also be faster. China is at the heart of this story. The country will continue to be the leading engine for global growth for many years to come. 2020 was a milestone in the shift of economic gravity as China attracted more foreign investment than the USA for the first time and the number of Chinese companies on the Fortune Global 500 (124) overtook the USA (121). 
It is not only between states that this gradual diffusion of power is occurring. Non-state actors from multinational corporations and philanthropists to civic groups and terrorist networks play an increasingly important role in global affairs, with the power to both create international problems and solve them. While the initial stages of the pandemic seemed to reassert the importance of states as the only agents with the power to take major steps such as close borders and enforce lockdowns, later stages have highlighted the importance of non-state actors. Transnational networks of research institutes, businesses, and foundations played a crucial role in vaccine development and distribution. Technology companies, whose tools played a crucial role in containment efforts and adaptations during the pandemic, have seen their wealth soar. The five leading US tech giants now have a combined market capitalization of roughly USD 7 trillion-greater than the GDP of every country except China and the USA.

Given the trends outlined above, in the post-pandemic era, our global governance framework must adapt to give developing countries a stronger voice in decision making, while harnessing the combined strengths of non-state actors to work on global challenges.

\subsection{A More Interdependent World}

Interdependence is the next feature that Global Governance 2.0 must be equipped for. It might surprise some to talk of rising interdependence when globalization and long cross-border supply chains are increasingly being questioned. Yet the fates of different countries are more entwined than at any point in human history, and this is only becoming more so.

Rising interdependence stems from two related sources. The first is cross-border flows of people, goods, capital, ideas, and data, which are broader and deeper than ever. These flows tie the interests of different countries together through global supply chains, cultural flows, and global finance. While the movement of goods and people was severely disrupted during the pandemic, global trade has recovered faster than expected, dispelling speculation that COVID-19 would be the death knell for global supply chains. International travel remains curtailed for the time being, but in the meantime, other cross-border flows such as data have accelerated, as discussed below.

Dense cross-border linkages contributed to the rapid global spread of COVID19, which brings us to the other driver of interdependence: the rise of transnational challenges. In the twenty-first century, the most serious existential threats faced by humanity — such as climate change, infectious disease, and nuclear weapons — share an important commonality; they pay no heed to national boundaries and can only be addressed through global, multilateral efforts.

What's more, transnational threats intersect in myriad ways. For example, climate change could also increase the risk of future pandemics by damaging natural habitats and raising the risk of zoonotic transmission. Climate change can also act as a destabilizing "risk multiplier" for geopolitics. It will aggravate stress on societies 
and institutions by exacerbating demographic pressures from climate migration and open new areas for rivalry.

Our current system of global governance was designed in an age when the most salient security threats that countries faced were those emanating from other states. But deepening cross-border linkages and shared global threats mean that no country is an island in the post-pandemic era. The purpose of Global Governance 2.0 will perhaps be less about preventing conflict between states, though that remains a crucial function and more about facilitating collective responses to the myriad shared threats we face.

\subsection{A More Digital World}

Staying with the theme of growing interconnectedness, perhaps nowhere is more evident than in the rise of transnational data flows and the global digital economy. Just as oil opened new possibilities for commerce and trade in the last century, data has become the lifeblood of global growth in the twenty-first century. Trade in digital services is booming. Data flows increasingly underpin trade in physical goods, too, supporting complex global value chains and emerging technologies such as blockchain, artificial intelligence, and the Internet of Things.

The pandemic has only served to accelerate digitalization. Data flows soared in 2020 as work, play, and education shifted online. International internet traffic surged $48 \%$ from mid-2019 to mid-2020 according to data from TeleGeography. ${ }^{1}$ One study found that cross-border e-commerce sales of discretionary goods spiked $53 \%$ in the second quarter of $2020 .^{2}$ Many businesses and organizations have had to adopt digitized models amidst the pandemic, including my own thinktank which has shifted to virtual event formats that allow people anywhere on earth to participate or watch.

While the full implications of digitalization for global governance have yet to become clear, they are sure to be profound and manifold.

First, the digital economy is arguably the area where global economic governance is weakest at present. As cross-border data flows soar, our global trade rules have barely changed since the 1990s. In the absence of shared global norms on how data flows should be governed, domestic policymakers everywhere are developing their own "patches" to regulate data and protect national security and their citizens' privacy. According to the OECD, the number of data regulations has risen from around 50 worldwide in the early 2000 s to just under 250 in 2019 . The patchwork nature of these rules is making things more complex for firms and stifling the potential of the global digital economy, which should be a bright spot in the postpandemic economic recovery. These gaps in global data governance are also creating friction between nations.

\footnotetext{
${ }^{1}$ https://blog.telegeography.com/internet-traffic-and-capacity-in-covid-adjusted-terms.

${ }^{2}$ DHL Global Connectedness Index 2020.
} 
Second, digitalization will have wide-reaching impacts on the real economy and societies around the world. Change will accelerate as production is dematerialized. Machines that drove earlier waves of globalization had to be made and shipped before use. Upgrading took time and considerable expense. Today, algorithms that overturn industries can be updated instantly at zero marginal cost. Digitalization and the associated technologies of the Fourth Industrial Revolution, such as AI, Internet of Things, and robotics, have the potential to drive inclusive global growth, but will also have a destabilizing effect on many communities and industries. If not addressed, these disruptions and the continuing digital divide may worsen inequality between and within countries.

Digitalization has caused strains on our current global governance framework, but it also creates new imperatives for cooperation - in particular, to develop a new framework that can support the safe and healthy growth of the global digital economy, and to build out digital infrastructure so that all can benefit from this growth.

\subsection{The Rise of Regionalism}

In recent years, the strains on global governance-such as the weakening of the UN, failure to reform Bretton Woods institutions, and breakdown of WTO negotiationshave led to a proliferation of multilateral initiatives at regional levels.

As global trade rules fray, a patchwork of regional deals has emerged as vehicles for deeper liberalization. The new free trade pact between the USA, Mexico, and Canada (USMCA) came into force in 2020, followed by the African Continental Free Trade Area (AfCFTA), which started trading at the start of 2021. Asia in particular is a locus for regional multilateralism. After it was abandoned by the USA, the reformed Trans-Pacific Partnership (TPP) (also known as the Comprehensive and Progressive Agreement for Trans-Pacific Partnership or CPTPP) was revived and came into force at the start of 2019. The Regional Comprehensive Economic Partnership (RCEP), set to be the world's largest Free Trade Agreement (FTA), was signed in November 2020. These living agreements will continue to evolve and will likely attract new members, offering a flexible, multitrack path to economic integration in Asia. For example, the more rigorous CPTPP may help to set standards for future trade for advanced economies, while the less-demanding RCEP will offer a way for developing countries to participate in free trade.

Some of these new regional multilateral initiatives address existing gaps in global governance. For example, the CPTPP includes rules on e-commerce. The Asian Infrastructure Investment Bank (AIIB), launched in 2014, aims to help close the yawning infrastructure gap, which existing multilateral development banks such as the World Bank have not been able to resolve. One of the tasks for Global Governance 2.0 is to accommodate these regional arrangements, exploit synergies with them, and help to coordinate so that they work together harmoniously. 


\subsection{The Age of Geoeconomics}

The fifth megatrend that Global Governance 2.0 must deal with is the rising specter of "geoeconomics"- the use of economic tools to advance geopolitical objectives.

Until relatively recently, economic cooperation served as a ballast for the international system. Global institutions underpinned a virtuous cycle of cooperation and prosperity, providing powerful incentives to follow rules and avoid confrontation with other countries. However, in our present times, economic relations are increasingly a source of friction that undermines international cooperation and global governance. The use of sanctions is rising and struggles over strategic technologies are a growing flashpoint in international relations. States are increasingly willing to weaponize global networks for finance or critical inputs for their own strategic ends.

The rise of economic statecraft began to cast a shadow over the global economy even before the pandemic dealt it another blow. COVID-19 has increased calls to "reshore" production and some governments are intervening to draw supply chains home. Even the distribution of vaccines and critical medical equipment has been caught up in politics.

As Pascal Lamy, former WTO director-general, has pointed out, in the aftermath of the pandemic, a certain degree of "precautionism"-legitimate safeguarding of citizen needs - is to be expected. ${ }^{3}$ But mechanisms are needed to ensure this is done in a transparent, coordinated manner and does not slide into more sticky and harmful forms of protectionism.

The WTO is the obvious solution to push back against protectionism and the weaponization of economic policy. But like other global institutions, it has been weakened by years of deadlock and fallen far behind the realities of the twenty-first century global economy. Our new system of global governance must find ways to contain dangerous tendencies toward economic statecraft and ensure that competition between great powers remains healthy, to ensure that the global economy remains open and inclusive, and remains a force for peace and prosperity.

\section{A Vision for Global Governance 2.0}

Global Governance 1.0 was designed for a world in which a few powerful countries called the shots; a world in which national boundaries were all important and the most pressing problems arose within or between states. As described above, we now live in an increasingly digital and multipolar world linked by cross-border flows and global challenges. Economic relations have grown fractious and regional institutions have become some of the most dynamic vehicles of multilateralism.

To adapt to these realities, Global Governance 2.0 will need to embody three principles. First, it needs to be more inclusive. That means better representing voices

\footnotetext{
${ }^{3}$ https://www.afr.com/world/europe/trade-s-new-bogeyman-isn-t-protectionism-it-s-precautio nism-20200516-p54tj2.
} 
and interests of emerging economies and mobilizing a new set of actors to work on global problems, including both developing countries and non-state actors.

The second principle is that global governance needs to be more integrated. Complex, cross-cutting challenges, such as climate change, need to be addressed in an integrated manner, accounting for links between different sectors and issues, based on strong links between global and regional organizations, international financial institutions, and other global alliances and institutions.

Third, our post-pandemic world calls for global institutions that are more flexible. Network science has shown the importance of both strong and weak ties. Small groups are good at getting things done, while large ones maximize participation and the flow of information and innovation. Rather than sticking to large, unwieldy member-driven formats for all purposes, global mechanisms should be tailored to the job at hand. For some purposes, such as kickstarting the process to reform key global institutions, a smaller group of key powers may be preferable. For other tasks, it may be more suitable to forge a broad and inclusive group of nations and other stakeholders such as businesses, cities, and universities.

There is a growing consensus that the next iteration of global governance needs to embody the guiding principles of being inclusive, integrated, and flexible. UN Secretary-General António Guterres advocates a "networked multilateralism" that better links various global and regional institutions. ${ }^{4}$ Thomas Friedman, New York Times columnist, and fellow contributor to this volume, says that the only way to govern our twenty-first-century world is through "global complex adaptive coalitions." Writing in Foreign Affairs, Anne-Marie Slaughter and Gordon LaForge call for a more participatory order that is rationalized around what they call "impact hubs"-issue-specific organizations that sit at the center of important actors working on a particular problem, coordinating their collective work toward common goals and outcomes. ${ }^{6}$

As for what a more inclusive, flexible, and integrated Global Governance 2.0 would look like in practice, there are three areas to think about. First, existing global institutions such as the UN, IMF, World Bank, and WTO would remain at the core, updated to give developing countries more of a say and to better focus on twenty-first-century issues like climate change and the digital economy. Second, underneath this global framework, new regional multilateral initiatives made up of smaller, more dynamic groupings of countries would be allowed to develop and explore new pathways for cooperation that could eventually also feedback to the global level. Third, new global institutions could be created, tailored to niches and problems not adequately covered by the present system, designed to complement the existing system and harness the power of diverse stakeholders, including non-state actors, to work on a common problem. The next and final section of this essay looks ahead to China's role in rebuilding post-pandemic global governance. Included in

\footnotetext{
${ }^{4}$ https://www.un.org/press/en/2020/sgsm20264.doc.htm.

${ }^{5}$ https://global.chinadaily.com.cn/a/202104/14/WS60764ba2a31024ad0bab5670.html.

${ }^{6} \mathrm{https}: / /$ www.foreignaffairs.com/articles/world/2021-02-16/opening-order.
} 
these thoughts are outlines of some proposals for steps China could take to boost governance in these three areas.

\section{China's Role in Global Governance 2.0}

China has benefited enormously from participating in the current system of Global Governance 1.0. Embracing globalization and its institutions such as the WTO, IMF and World Bank spurred development and helped to transform the country. After several decades of rapid growth, China is now the second-largest economy and poised to be the largest in the not-too-distant future.

As its influence grows, China has growing capabilities, and indeed a growing responsibility, to help address gaps in global governance and increase its contribution to global public goods. For many years, the reform of global governance has been held back by a lack of global leadership and consensus. China is well placed to help overcome this gridlock and galvanize international cooperation. As it transitions from being a developing nation into a developed one, China can help bridge the divides that have stalled reform. China is also well placed to propose new global governance solutions for the post-pandemic era. The rest of this essay is devoted to five ways China could do this in the three areas outlined above, namely promoting the reform of existing institutions, participating in next-generation regional agreements, and finally proposing new solutions for global governance.

\subsection{Create a Dedicated UN Body for Climate Change}

Despite its weaknesses, the UN continues to play an irreplaceable role in the international system. China should work to reinvigorate the UN to serve as the linchpin of a new overlapping system of institutions and coalitions that make up Global Governance 2.0.

The structure that is most obviously outdated is the UN Security Council, whose five permanent veto members reflect the outcomes of the Second World War rather than contemporary realities. However, reforming this body has long proved an intractable problem and for now there are no ideal solutions and no easy way forward.

In the short term, green issues may offer a more promising field to forge consensus and meaningful reform. In particular, China could work with other partners to promote the creation of a dedicated UN institution focused on climate change as a unique crisis that affects many areas of global cooperation. The UN already plays a leading role in addressing climate change through the UN Environmental Program (UNEP) and UN Framework Convention on Climate Change (UNFCCC). However, the former's work spans many other environmental issues, and the UNFCCC is limited by its need for universal consensus via infrequent moments of agreement between members. A permanent and dedicated UN climate change body could 
serve to build continuous momentum for climate governance and foster collaboration between various stakeholders - not just states, but also firms and other organizations at the local, regional, and global level — to nurture long-term policy and technological solutions.

\subsection{Promote WTO Reform}

Reviving the WTO is another priority in the course of post-pandemic recovery. The aftermath of the Second World War and the Global Financial Crisis of 2007-2008 shows that trade can support economic recovery after a major global calamity. As the world emerges from the COVID-19 crisis, the steps we take to limit or liberalize trade can profoundly affect the world's economic trajectory. The WTO is the obvious vehicle to manage this process, but unfortunately, the institution has failed to keep up with important developments in the global economy and its dispute settlement mechanism remains paralyzed.

A plan is needed to breathe life back into the WTO. The WTO secretariat could play a bigger role in driving change and adjustments like using more flexible plurilateral agreements would also help. However, ultimately the WTO remains a membership-driven organization and real change requires that major powers play ball. This has proved challenging in recent years, but COVID-19 and the change of administration in Washington have widened the realms of political possibility. China should work with leading powers - the USA and EU in particular-to kickstart the WTO reform process so that it can be an institutional catalyst for postpandemic economic recovery. Completing the WTO's e-commerce negotiations has also become a priority as billions go online to shop, study, work, or seek health care.

\subsection{Join the CPTPP}

While working to revive the global free trade agenda, China should also be an active participant in FTAs developing at the regional level. In years to come, membership in the RCEP will boost China's growth and solidify the nation's place at the heart of regional supply chains. Looking ahead, China should move toward joining the CPTPP, a higher standard FTA geared to advanced economies.

Joining the 11-member CPTPP agreement would push back against decoupling and protectionism and give China better access to one of the world's most dynamic regional markets. It would also provide an external impetus for the next phase of reform and opening - just as WTO entry did two decades ago. In particular, CPTPP principles are well aligned with China's goals to improve IPR protection and reform state-owned enterprises.

In the long term, an enlarged CPTPP could provide a blueprint for reforming the WTO and getting the global free-trade agenda back on track. Given that President 
Biden has said he is open to rejoining the pact, there is even a chance that China and the USA could one day come under the CPTPP's common umbrella. Regardless of the course Washington takes, Chinese membership could help reduce friction and the rise of geoeconomics by aligning China closer with progressive global trade norms.

\subsection{Multilateralize the Belt and Road}

Moving on to ways in which China can propose and develop new innovations for global governance, the fourth suggestion is to reconfigure the Belt and Road Initiative (BRI) as a multilateral endeavor for global governance and development.

Since it was launched in 2013, the BRI has become a vector of globalization, growth, and investment in many regions. Belt and Road projects have created nearly 300,000 jobs. The World Bank estimates that host countries have reduced shipping times by up to $3.2 \%$, and trade costs by up to $2.8 \% .^{7}$ In addition, the initiative has helped build up the so-called "soft" infrastructure such as education, healthcare, and other services.

However, two factors contribute to a more challenging environment ahead for the BRI in the post-pandemic era. First, the BRI has evolved beyond expectations and become truly global, with over 130 countries having signed cooperation agreements. As the initiative links diverse geographies, it also needs to engage with a more complex group of stakeholders, who have their own interests and development plans. Second, a shift in the geopolitical climate has cast a shadow of suspicion over the BRI. Ironically, the problems that call for a global vision-economic uncertainty, protectionism, and mistrust - have created headwinds for the very initiative that could be part of the solution. At the international and local levels, some have politicized and misrepresented the initiative to serve their own interests.

Given these conditions, concrete steps must be taken to ensure that the BRI can fulfill its long-term potential to contribute to global governance and development in the post-pandemic era.

First, an international cooperation committee could be created to help the Belt and Road plan transition from a bilateral to a more multilateral approach. This committee would comprise a selection of representatives from key international organizations. Embedding a broad spectrum of experiences and perspectives into the advisory apparatus of the initiative would enhance its multilateral nature and help address concerns over its sinocentric approach.

Second, the initiative needs deeper engagement with international organizations, 29 of which have come on board. Working closely with established institutions, such as the World Bank, brings in additional expertise and resources, and helps ensure BRI projects meet the highest international standards.

\footnotetext{
${ }^{7}$ https://documents.worldbank.org/en/publication/documents-reports/documentdetail/592771539 630482582/how-much-will-the-belt-and-road-initiative-reduce-trade-costs.
} 
Third, other mechanisms for multilateralizing the plan could be extended. For example, an overseas Belt and Road arbitration center could be set up, as a counterpart to the BRI courts in Shenzhen and Xi' an. There could even be an arbitration agency in Geneva. This would build transparency and trust in the trade plan's institutional framework. To increase transparency around the plan, additional platforms could be set up, such as an open online system for project bidding worldwide.

\subsection{Upgrade the AIIB into a Global Infrastructure Bank}

Continuing the theme of multilateralizing the BRI, to date, the Asian Infrastructure Investment Bank (AIIB) provides the most compelling model for how this might be achieved. Over the last six years, the AIIB has established itself as an effective multilateral development bank (MDB) and successfully integrated into the international financial architecture. Having attracted advanced economies as voting members and adopted the high standards of other MDBs, it has gained recognition from multilateral organizations like the UN and AAA ratings from leading rating agencies.

With a fresh capital injection and expanded membership, the bank would be well placed to expand its remit and become the Global Infrastructure Investment Bank (GIIB). This would involve inviting new members to play major roles-notably the USA and Japan—as well as getting more countries in other regions such as Africa and Latin America to join. In addition, the GIIB could form a special body for multilateral actors including MDBs and regional organizations to enhance coordination between existing infrastructure initiatives around the world.

To succeed, the GIIB would need a clearly defined mission. One priority would be sustainable infrastructure. Making the wrong investments during post-pandemic recovery could lock countries into carbon-intensive development paths for decades to come. Aligning investment with climate goals would also be a key task for the new bank.

Another top priority would be inclusive connectivity, in particular, closing the "digital divide." As discussed above, the pandemic has spurred digitalization and online forms of work, study, and business. However, 3.7 billion people still lack Internet access. ${ }^{8}$ The GIIB could take a lead in digital infrastructure financingan area that accounts for only around 1\% of total Multilateral Development Bank (MDB) commitments at present. ${ }^{9}$

The third priority would be mobilizing private capital. With public finances limited in the wake of COVID-19, innovative financing models are needed to incentivize private sector involvement. This is something the AIIB is already focusing on, with a goal to boost the share of private financing to $50 \%$ by 2030 .

\footnotetext{
${ }^{8}$ https://www.weforum.org/agenda/2020/04/coronavirus-covid-19-pandemic-digital-divide-int ernet-data-broadband-mobbile/.

${ }^{9} \mathrm{https} / / /$ www.aiib.org/en/policies-strategies/operational-policies/digital-infrastructure-strategy/. content/_download/Full-DISA-Report_final-with-Appendix-2020-01-10.pdf.
} 
The new GIIB could play an important role in the "networked multilateralism" of Global Governance 2.0 and would be designed to complement existing MDBs, not compete with them. The AIIB has pursued a collaborative model and most of its projects have been co-financed with other MDBs. As a global bank, it could further develop this model and find new ways to co-finance, share expertise, and tap synergies with other organizations. This collaborative role has grown more important with the proliferation of integration arrangements at the national and regional levels. At present, these don't always join up well. The GIIB could serve as a multilateral platform to enable long-term planning and coordination so that intra- and interregional connectivity can be enhanced more efficiently.

\section{Conclusion}

In the first half of the twentieth century, in the absence of effective global governance mechanisms, unchecked forces of fragmentation, economic hardship, and polarization led to two devastating world wars. To prevent this from happening again, after the Second World War, countries from around the world came together at Bretton Woods and other landmark conferences to build a new system of global governance that would promote international cooperation, stability, and peace and prosperity.

Today, like after the Second World War, the world faces major challenges, not only in the short-term to recover from the pandemic but also in the long-term to overcome global threats like climate change, which no country can solve alone. As we emerge from COVID-19, there is a unique opportunity for a long-overdue "Bretton Woods 2.0" moment to rethink global governance and forge multilateral institutions that better reflect realities of the post-pandemic world.

Global Governance 2.0 needs to be more inclusive and geared to twenty-firstcentury problems like climate change, infectious diseases, and addressing inequality by boosting free trade, overcoming the global infrastructure gap, and closing the digital divide. China too faces challenges, with pressures at home as well as questions about how other countries will respond to its rise. But it is in the interest of both China and other countries that the world's most populous country, and soon-to-be largest economy, play a leading role in shaping the next iteration of global governance. China can, and should, help lead by supporting the update and strengthening of existing institutions. In addition, China should be proactively participating in forward-looking regional initiatives. And in an even broader sense, China should be drawing on its knowledge as the longest continuous civilization in the world and using these strengths to propose its own solutions to pressing global issues.

Huiyao Wang is the Founder and President of Center for China and Globalization (CCG), a think tank ranked among top 100 think tanks in the world. He is also Dean of the Institute of Development Studies of Southwestern University of Finance and Economics of China, Vice Chairman of China Association for International Cooperation and a Director of Chinese People's Institute of 
Foreign Affairs. He is currently a steering committee member of Paris Peace Forum and an advisory board member of Duke Kunshan University. He served as an expert for World Bank, IOM and ILO. He pursued his Ph.D. studies at University of Western Ontario and University of Manchester. He was a Senior Fellow at Harvard Kennedy School and a Visiting Fellow of Brookings Institute. His books in English include: Globalizing China (2012); China Goes Global (2016); the Handbook on China and Globalization (2019); and the Globalization of Chinese Enterprises (2020).

Open Access This chapter is licensed under the terms of the Creative Commons AttributionNonCommercial-NoDerivatives 4.0 International License (http://creativecommons.org/licenses/bync-nd/4.0/), which permits any noncommercial use, sharing, distribution and reproduction in any medium or format, as long as you give appropriate credit to the original author(s) and the source, provide a link to the Creative Commons license and indicate if you modified the licensed material. You do not have permission under this license to share adapted material derived from this chapter or parts of it.

The images or other third party material in this chapter are included in the chapter's Creative Commons license, unless indicated otherwise in a credit line to the material. If material is not included in the chapter's Creative Commons license and your intended use is not permitted by statutory regulation or exceeds the permitted use, you will need to obtain permission directly from the copyright holder.

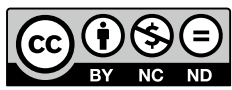

